\title{
PERBANDINGAN TEKANAN DARAH ANTARA ANAK YANG TINGGAL DI PEGUNUNGAN DAN PESISIR PANTAI
}

\author{
${ }^{1}$ Queen Mandang \\ ${ }^{2}$ Adrian Umboh \\ ${ }^{2}$ Stefanus Gunawan
}

\author{
${ }^{1}$ Kandidat Skripsi Fakultas Kedokteran Universitas Sam Ratulangi Manado \\ ${ }^{2}$ Bagian Ilmu Kesehatan Anak Fakultas Kedokteran Universitas Sam Ratulangi Manado \\ Email: qnmariamandang@gmail.com
}

\begin{abstract}
Blood pressure in children varies because there are many factors that influence. One is geographic factors. Based on data from the Health Research in 2007 found that the prevalence of hypertension is highest in coastal areas while the lowest prevalence of hypertension in the coastal area. Altitude and different sodium intake on mountain and coastal areas are assumed to affect the blood pressure. This study aimed to determine the difference in blood pressure between children who live in the mountains and in the coast. We used descriptive analytic method with cross sectional design, with 107 samples according to criteria of children aged 6-12 years with no family history of obesity and hypertension. Data were obtained by using questionnaire, measurement of weight and height (BMI) and blood pressure measurement using a sphygmomanometer and cuff child. The results showed $15.5 \%$ of children with high-normal systolic pressure and $17.4 \%$ of children with high diastolic pressure in the mountains. In coastal areas, found $28 \%$ of children with normal systolic pressure-high, $13 \%$ of children of normal-high diastolic pressure, and 5\% of children of high diastolic pressure. These data were analyzed using Mann Whitney test, showing the results were not statistically significantly systolic $(\mathrm{p}=0.815)$ diastolic $(\mathrm{p}=0.221)$ so that $\mathrm{HO}$ and $\mathrm{H} 1$ is rejected. Conclusion: There was no difference in blood pressure among children aged 6-12 years who live in the mountains and the coast.
\end{abstract}

Keywords: child's blood pressure, mountains, coastal.

\begin{abstract}
Abstrak: Tekanan darah pada anak bervariasi karena ada banyak faktor yang memengaruhi. Salah satunya adalah faktor geografis. Berdasarkan data Riset Kesehatan Dasar tahun 2007 didapatkan prevalensi hipertensi tertinggi di wilayah pantai sedangkan prevalensi hipertensi terendah di wilayah pantai. Ketinggian lokasi dan asupan natrium yang berbeda pada daerah pegunungan dan pesisir pantai diasumsikan berpengaruh terhadap tekanan darah. Penelitian ini bertujuan untuk mengetahui perbedaan tekanan darah antara anak yang tinggal di pegunungan dan pesisir pantai. Metode penelitian deskriptif analitik dengan rancangan potong lintang, dengan 107 sampel sesuai kriteria anak umur 6-12 tahun tanpa obesitas dan riwayat keluarga hipertensi. Data diperoleh melalui kuesioner, pengukuran berat badan dan tinggi badan (IMT) dan pengukuran tekanan darah menggunakan sphygmomanometer dan manset anak. Hasil penelitian menunjukkan 15,5\% anak dengan tekanan sistolik normal-tinggi dan 17,4\% anak dengan tekanan diastolik tinggi pada daerah pegunungan. Pada daerah pesisir pantai ditemukan 28\% anak dengan tekanan sistolik normal-tinggi, $13 \%$ anak tekanan diastolik normal-tinggi, dan 5\% anak tekanan diastolik tinggi. Data ini dianalisis menggunakan uji mann whitney, menunjukkan hasil secara statistik tidak bermakna sistolik $(\mathrm{p}=0,815)$ diastolik $(\mathrm{p}=0,221)$ sehingga H0 diterima dan H1 ditolak. Simpulan: Tidak ada perbedaan tekanan darah antara anak berumur 6-12 tahun yang tinggal di pegunungan dan pesisir pantai.
\end{abstract}

Kata kunci: tekanan darah anak, pegunungan, pantai. 
Tekanan darah merupakan salah satu indikator penting dari pemeriksaan tanda vital manusia. ${ }^{1}$ Tekanan darah pada anak bervariasi karena ada banyak faktor yang memengaruhi antara lain usia, jenis kelamin, dan tinggi badan. Dikatakan normal apabila tekanan darah sistolik dan tekanan darah diastolik kurang dari persentil 90 berdasarkan faktor tersebut. Peningkatan tekanan sistolik dan diastolik diatas persentil ke-95 disebut sebagai hipertensi. $^{2}$

Hipertensi pada anak terdiri dari hipertensi primer / esensial dan hipertensi sekunder. Hipertensi primer adalah gangguan yang tidak jelas penyebabnya, dan paling banyak ditemukan pada dewasa, namun kejadiannya sudah dimulai pada masa bayi dan dapat diidentifikasi pada masa kanak.Sedangkan hipertensi sekunder paling banyak ditemukan pada anak dengan etiologi terbanyak berhubungan dengan penyakit parenkim ginjal. ${ }^{3}$ Pengukuran tekanan darah secara rutin membantu diagnosis dini hipertensi pada anak. Dengan melihat unsur keturunan dari hipertensi hal ini tentunya sangat penting. ${ }^{4}$

Ada banyak faktor resiko yang dapat mempengaruhi tekanan darah pada anak.Salah satunya adalah faktor geografis.Studi epidemiologi menunjukan adanya perbedaan antara masyarakat urban dan rural, dimana masyarakat urban lebih banyak mengalami hipertensi dibandingkan masyarakat rural. Letak geografis juga disebutkan memiliki pengaruh terhadap tekanan darah, yakni wilayah pesisir pantai lebih besar risikonya mengalami hipertensi dibandingkan di wilayah pegunungan. ${ }^{5}$

Perbedaan ketinggian suatu tempat memengaruhi beberapa fisiologi tubuh berkaitan dengan adanya gaya gravitasi.

Efek gravitasi pada tekanan vena

Dalam keadaan normal terdapat dua mekanisme kompensasi yang melawan efek gravitasi. Pertama, penurunan tekanan arteri rerata yang terjadi ketika seseorang berpindah dari posisi berbaring menjadi tegak memicu vasokonstriksi vena melalui saraf simpatis yang mendorong maju sebagian dari darah yang menumpuk. Kedua pompa otot rangka menginterupsi kolom darah dengan mengosongkan secara total segmen tertentu secara intermiten sehingga bagian tertentu dari vena tidak mengalami beban dari seluruh kolom vena dari jantung ke bagian tersebut. ${ }^{6}$

Berdasarkan data Riset Kesehatan Dasar tahun 2007 didapatkan bahwa prevalensi hipertensi tertinggi di Kepulauan Natuna (wilayah pantai) sebanyak 53,3\%, sedangkan prevalensi hipertensi terendah di Pegunungan Jayawijaya sebanyak $6,8 \% .^{6}$ Penelitian yang lain menunjukan hipertensi berdasarkan letak demografis di pedalaman $(17,6 \%)$ lebih besar dibandingkan di pesisir pantai (10\%). Hal ini mungkin bisa disebabkan oleh berbagai faktor yang lain. ${ }^{7}$

\section{METODE PENELITIAN}

Penelitian ini merupakan penelitian deskriptif analitik dengan rancangan potong lintang. Populasi dalam penelitian ini ialah murid yang tercatat di register SD Negeri II Motoling Dua (daerah pegunungan) dan di SD Negeri 86 Tuminting Manado (daerah pesisir pantai). Sampel penelitian adalah anak berumur 612 tahun tanpa riwayat keluarga hipertensi dan obesitas. Besar sampel ditentukan berdasarkan uji hipotesis terhadap rerata 2 populasi berpasangan dan di dapat hasil 52 sampel yang di genapkan menjadi 54 sampel di masing-masing populasi.

Variabel bebas dalam penelitian ini adalahpegunungan (dataran tinggi) dan pesisir pantai (dataran rendah), dengan variabel terikat adalah tekanan darah anak.

Pengumpulan data menggunakan kuesioner, pengukuran IMT dan tekanan darah pada anak, selanjutnya untuk mengetahui sebaran data dilakukan uji normalitas data dengan KolmogorovSmirnov Test. Data perbandingan dianalisisuji non parametrik dengan menggunakan Mann-Whitney Test SPSS.

\section{HASIL PENELITIAN}

Berdasarkan metode sampling, pada daerah pegunungan di SDN II Kecamatan Motoling terdapat 90 murid yang terdaftar, 
sebanyak 65 anak bersedia mengikuti penelitian dan melalui kuesioner didapati 13 anak memiliki riwayat keluarga hipertensi dan 52 anak tanpa riwayat keluarga. Pada daerah pesisir pantai di SDN 86 Manado Kecamatan Tuminting dari 103 murid yang terdaftar, sebanyak 76 anak bersedia mengikuti penelitian dan melalui kuesioner didapati 20 anak memiliki riwayat keluarga hipertensi dan 56 anak tanpa riwayat keluarga kemudian dikeluarkan 2 anak karena mengalami obesitas.Jumlah sampel yang dianalisis 52 anak pada daerah pegunungan dan 54 anak di daerah pesisir pantai.Keseluruhan sampel adalah 106 anak.

Tabel 1. Distribusi Tekanan Darah Sistolik Berdasarkan Jenis Kelamin

\begin{tabular}{|c|c|c|c|c|c|c|c|c|}
\hline \multirow{2}{*}{$\begin{array}{c}\text { Jenis } \\
\text { Kelamin }\end{array}$} & \multicolumn{3}{|c|}{ Pegunungan } & \multirow{2}{*}{ Jumlah } & \multicolumn{3}{|c|}{ Pesisir Pantai } & \multirow{2}{*}{ Jumlah } \\
\hline & $\mathrm{N}(\%)$ & NT(\%) & $\mathrm{T}(\%)$ & & $\mathbf{N}(\%)$ & NT(\%) & $\mathrm{T}(\%)$ & \\
\hline $\mathrm{L}$ & $21(40,3)$ & $5(9,7)$ & 0 & $26(50)$ & $21(39)$ & $7(13)$ & 0 & $28(52)$ \\
\hline $\mathrm{P}$ & $23(44,2)$ & $3(5,8)$ & 0 & $26(50)$ & $18(33)$ & $8(15)$ & 0 & $26(48)$ \\
\hline Jumlah & $44(84,5)$ & $8(15,5)$ & $\mathbf{0}$ & $52(100)$ & 39(72) & $15(28)$ & $\mathbf{0}$ & $54(100)$ \\
\hline
\end{tabular}

Keterangan $: \mathrm{N}=$ Normal $\mathrm{NT}=$ Normal Tinggi $\mathrm{T}=$ Tinggi

Dari penelitian didapati anak laki-laki di daerah pegunungan mempunyai tekanan darah sistolik normal tinggi lebih sedikit $(9,7 \%)$ dibandingkan dengan anak laki-laki di daerah pesisir pantai (13\%), begitu juga terlihat anak perempuan di daerah pegunungan memiliki tekanan darah sistolik normal tinggi lebih sedikit $(5,8 \%)$ dibandingkan anak perempuan di daerah pesisir pantai $(15 \%)$. Tidak ditemukan adanya tekanan darah sistolik tinggi baik pada anak laki-laki maupun perempuan pada kedua daerah (tabel 1).

Tabel 2. Distribusi Tekanan Darah Diastolik berdasarkan Jenis Kelamin

\begin{tabular}{|c|c|c|c|c|c|c|c|c|}
\hline \multirow{2}{*}{$\begin{array}{c}\text { Jenis } \\
\text { Kelamin }\end{array}$} & \multicolumn{3}{|c|}{ Pegunungan } & \multirow{2}{*}{ Jumlah } & \multicolumn{3}{|c|}{ Pesisir Pantai } & \multirow{2}{*}{ Jumlah } \\
\hline & $\mathrm{N}(\%)$ & NT(\%) & $T(\%)$ & & $\mathrm{N}(\%)$ & $\mathrm{NT}(\%)$ & $\mathrm{T}(\%)$ & \\
\hline $\mathrm{L}$ & $21(40,3)$ & $5(9,7)$ & 0 & $26(50)$ & $24(45)$ & $3(5,5)$ & $1(1,8)$ & $28(52)$ \\
\hline $\mathrm{P}$ & $22(42,3)$ & $4(7,7)$ & 0 & $26(50)$ & $20(37)$ & $4(7,4)$ & $2(3,7)$ & $26(48)$ \\
\hline Jumlah & $43(82,6)$ & $9(17,4)$ & $\mathbf{0}$ & $52(100)$ & $44(82)$ & $7(13)$ & $3(5)$ & $54(100)$ \\
\hline
\end{tabular}

Keterangan $: \mathrm{N}=$ Normal $\mathrm{NT}=$ Normal Tinggi $\mathrm{T}=$ Tinggi

Tekanan darah diastolik berdasarkan jenis kelamin pada daerah pegunungan dan pesisir pantai dapat dilihat pada Tabel 2.Anak laki-laki pada daerah pegunungan lebih banyak mempunyai tekanan darah diastolik normal tinggi $(9,7 \%)$ dibandingkan anak laki-laki di daerah pesisir pantai $(5,5 \%)$, begitu juga terlihat 
anak perempuan pada daerah pegunungan memiliki tekanan darah diastolik normal tinggi sedikit lebih banyak $(7,7 \%)$ dibanding anak perempuan di daerah pesisir pantai $(7,4 \%)$. Tidak ditemukan tekanan darah diastolik tinggi pada daerah pegunungan baik anak laki-laki maupun perempuan. Sedangkan pada daerah pesisir pantai ditemukan anak laki-laki dengan tekanan diastolik tinggi $(1,8 \%)$ dan anak perempuan dengan tekanan diastolik tinggi $(3,7 \%)$ (Tabel 2).

Tabel 3.Analisis Perbandingan Tekanan Darah Sistolik dan Diastolik Pegunungan dan Daerah Pantai
Daerah
Z
$\mathrm{P}$

\begin{tabular}{lll}
\hline $\begin{array}{l}\text { Sistolik Pegunungan } \\
\text { dan Pesisir Pantai }\end{array}$ & 0,234 & 0,815 \\
\hline $\begin{array}{l}\text { Diastolik Pegunungan } \\
\text { dan Pesisir Pantai }\end{array}$ & 0,003 & 0,997 \\
\hline
\end{tabular}

Perbandingan tekanan darah sistolik pada daerah pegunungan dan daerah pesisir pantai diperoleh hasil nilai $\mathrm{z}$ hitung sebesar 0,234 dan nilai signifikansi $P=0,815$ $(>0,05)$ yaitu tidak ada perbedaan tekanan darah sistolik di daerah pegunungan dan pesisir pantai. Perbandingan tekanan darah diastolik pada daerah pegunungan dan daerah pesisir pantai diperoleh hasil nilai z hitung sebesar 0,003 dan nilai signifikansi $P=0,997 \quad(>0,05)$ yaitu tidak ada perbedaan tekanan darah diastolik di daerah pegunungan dan pesisir pantai (Tabel 3)

\section{BAHASAN}

Berdasarkan hasil analisis perbandingan Mann-Whitney, tidak ada pebedaan tekanan darah sistolik antara daerah pegunungan dan daerah pantai, dengan nilai $\rho=0,815(>0,05)$ dan tidak ada pebedaan tekanan darah diastolik antara daerah pegunungan dan daerah pantai dengan nilai $\rho=0,997>0,05$ ).

Dilihat dari jumlah persentase, anak dengan tekanan darah normal-tinggi (prehipertensi) dan tekanan darah tinggi (hipertensi) ditemukan daerah pesisir pantai lebih tinggi dibandingkan daerah pegunungan dengan nilai sistolik (28\%) dan diastolik (18\%), namun hasil ini secara statistik tidak bermakna sistolik $P=0,590$ diastolik $P=0,221$.

Tekanan darah pada anak diketahui dapat bervariasi oleh berbagai faktor. Sebagaimana High Blood Pressure Education Program (NHBPEP) yang menetapkan klasifikasi nilai tekanan darah berdasarkan jenis kelamin, usia, dan tinggi badan. $^{2}$ Hal ini juga dipengaruhi oleh berbagai faktor lain seperti obesitas, aktifitas fisik, dietetik, dan termasuk lingkungan tempat tinggal. ${ }^{3,8}$ Lingkungan tempat tinggal pada kedua daerah ini mempunyai perbedaan ketinggian dimana daerah pegunungan berada jauh lebih tinggi dibandingkan dengan daerah pesisir pantai. Tekanan udara di pesisir pantai (dataran rendah) lebih tinggi dibanding dengan pegunungan (dataran tinggi). Hal ini berkaitan dengan adanya faktor gravitasi bumi. ${ }^{6,9}$

Beberapa penelitian mengenai hipertensi di daerah pesisir pantai dikaitkan dengan gaya hidup masyarakat mengkonsumsi garam dan air yang mengandung banyak natrium (sumber air dekat pantai) dibandingkan dengan gaya hidup masyarakat pegunungan yang mengkonsumsi lebih banyak sayur dan 
buah. $^{10-12}$ Farid dalam penelitiannya mengenai hubungan asupan natrium, kalium, magnesium, dan serat dengan tekanan darah pada remaja mendapat hasil bahwa terdapat hubungan yang signifikan antara asupan natrium dengan tekanan darah pada remaja. ${ }^{11}$ Sementara asupan kalium dan magnesium yang terkandung dalam buah dengan konsumsi yang adekuat disebut berhubungan negatif dengan tekanan darah tinggi dan berperan dalam menurunkan tekanan darah. Penelitian serupa mengenai hubungan asupan kalium dengan tekanan darah dilakukan oleh Rahayuningsih dengan meneliti hubungan konsumsi sayur dan buah dengan tekanan darah pada anak sekolah dasar di Semarang dengan hasil subjek yang bernilai normaltinggi sebanyak 6,4\% dari 89,4\% subjek yang kurang menkonsumsi sayur dan buah namun secara statistik tidak bermakna. ${ }^{12}$

Lingkungan tempat tinggal anak dibesarkan memengaruhi pola hidup dan aktifitas yang beragam. Gaya hidup masyarakat pinggiran (daerah pesisir pantai) yang banyak tergolong keluarga miskin berbeda dengan gaya hidup di pedesaan (daerah pegunungan) yang diasumsikan lebih banyak mengonsumsi sayur dan buah. ${ }^{11-13}$ Terdapat banyak faktor yang saling memengaruhi. Dan dengan kemajuan modern, gaya hidup di berbagai tempat tinggal dapat berubah dan berpengaruh terhadap nilai tekanan darah anak baik di daerah pegunungan maupun daerah pesisir pantai.

\section{SIMPULAN}

Dari hasil penelitian yang diperoleh maka dapat diambil kesimpulan bahwa ditemukan cukup banyak anak dengan prehipertensi di pegunungan dan di pesisir pantai.Namun secara statistik tidak ada perbedaan tekanan darah antara anak berumur 6-12 tahun yang tinggal di pegunungan dan pesisir pantai.

\section{SARAN}

Perlu dilakukan penelitian lebih lanjut mengenai tekanan darah di pegunungan dan pesisir pantai dalam jumlah sampel yang lebih banyak dan cakupan yang lebih luas.

Perlu dilakukan penelitian mengenai hubungan tempat tinggal dengan tekanan darah anak dan gambaran asupan gizi dalam makanan terhadap tekanan darah anak.

Perlu dilakukan pengukuran tekanan darah pada anak secara rutin minimal satu kali dalam setahun, untuk mendeteksi adanya kenaikan tekanan darah pada anak.

\section{DAFTAR PUSTAKA}

1. Bickley S. Buku ajar pemeriksaan fisik. Ed8. Alih bahasa; Andry Hartono. Editor; Linda Dwijatanthi, Andita Novrianti, Sherli Karolina. Bate's guide to physical examination \& history taking. Jakarta: EGC; 2009. p. 668.

2. National High Blood Pressure Education Programm Working Group on High Blood Pressure in Children and Adolescent. The fourth report on diagnosis, evaluation, and treatment of high blood pressure in children and adolescents. Pediatrics. 2004;114:55576.

3. Bahrun D. Hipertensi sistemik. Dalam: Alatas H, Tambunan T, Trihono PP, dan Pardede SO, penyunting. Buku ajar nefrologi anak. Ed- 2. Jakarta: Balai Penerbit FK UI; 2009. p. 242-90.

4. Lumoindong A, Umboh A, Masloman N. Hubungan obesitas dengan profil tekanan darah pada anak 10-12 tahun di kota Manado. Jurnal e-Biomedik [eBM]. 2013;1:147-53.

5. Bustan M N. Epidemiologi penyakit tidak menular. Jakarta: Rineka Cipta; 2008.

6. Lauralee $\mathbf{S}$. Fisiologi manusia: dari sel ke system. Ed-6. Editor; Nella Yesdelita. Human physiology: from cells tosystems. Jakarta: EGC; 2013. p. 371,400-5.

7. Laporan Nasional Riskesdas 2007 http://www.litbang.depkes.go.id/bl riskesdas2007

8. Kartikawati A. Prevalensi dan determinan hipertensi pada pasien puskesmas di Jakarta Utara tahun 2007. FKM UI [cited 31 Agustus 2013]. Available from:

http://www.google.com/url?sa=t\&rct= $\mathrm{j} \& \mathrm{q}=\&$ esrc $=\mathrm{s} \&$ source $=$ web $\& \mathrm{~cd}=4 \& \mathrm{ca}$ 
$\mathrm{d}=\mathrm{rja} \&$ ved $=0 \mathrm{CDUQFjAD \& url}=\mathrm{http} \% 3$ A\%2F\%2Flontar.ui.ac.id\%2Ffile\%3Ffi le\%3Ddigital\%2F122551-S-5407-

Prevalensi\%2520danliteratur. pdf\&ei=jTFIUvW9EMWArgeuuIHAB w\&usg=AFQjCNFYPcCsSx2Qwe8wp Z6nNylmg703dQ\&bvm=bv.53217764, d.bmk

9. Ethel S. Anatomi dan fisiologi untuk pemula. Editor; Palupi Widayastuti.

Anatomy and physiology: an easy learner. Jakarta: EGC; 2004. p. 221-22.

10.Ariani A, Lisma TE, Lubis IZ, Ramayati R. Blood pressure values of elementary school - age children at the high and seashore areas. Pediatr Indones. 2002;
40: $24-49$.

11.Farid A. Hubungan antara asupan natrium, kalium, kalsium, magnesium, dan serat dengan tekanan darah pada remaja. [Artikel penelitian]. [Semarang]. Fakultas Kedokteran Universitas Diponegoro; 2010.

12. Rahayuningsih I. Hubungan konsumsi sayur dan buah dengan tekanan darah anak sekolah dasar. [Artikel penelitian]. [Semarang]. Fakultas Kedokteran Universitas Diponegoro; 2010.

13.Sunardi T, Soetardjo S. Hidangan sehat untuk hipertensi. Jakarta. Gramedia Pustaka Utama, 2005. 